\title{
Massisteria marina Larsen \& Patterson 1990, a widespread and abundant bacterivorous protist associated with marine detritus
}

\author{
David J. Patterson ${ }^{1}$, Tom Fenchel ${ }^{2}$ \\ ${ }^{1}$ Department of Zoology, University of Bristol, Bristol BS8 1UG, United Kingdom \\ ${ }^{2}$ Marine Biological Laboratory, Strandpromenaden, DK-3000 Helsingør, Denmark
}

\begin{abstract}
An account is given of Massisteria marina Larsen \& Patterson 1990, a small phagotrophic protist associated with sediment particles and with suspended detrital material in littoral and oceanic marine waters. It has been found at sites around the world. The organism has an irregular star-shaped body from which radiate thin pseudopodia with extrusomes. There are 2 inactive flagella. The organism is normally sedentary but, under adverse conditions, the arms are resorbed, the flagella become active, and the organism becomes a motile non-feeding flagellate. The ecological niche occupied by this organism and its phylogenetic affinities are discussed.
\end{abstract}

\section{INTRODUCTION}

Much of the carbon fixed in marine ecosystems is degraded by microbial communities and it is held that protists, especially flagellates under $10 \mu \mathrm{m}$ in size, exercise one of the principal controlling influences over bacterial growth rates and numbers (Fenchel 1982, Azam et al. 1983, Ducklow 1983, Proctor \& Fuhrman 1990). Detrital aggregates, whether benthic or in the water column, may support diverse and active microbial communities that include flagellates (Wiebe \& Pomeroy 1972, Caron et al. 1982, Goldman 1984, Davoll \& Silver 1986, Caron 1987, Biddanda 1988, Biddanda \& Pomeroy 1988, Karl et al. 1988, Bak \& Nieuwland 1989, Patterson et al. 1989). Apart from species with siliceous skeletal material, few small heterotrophic flagellates have been described. The belief that a lack of awareness of the diversity of these organisms may impede an understanding of the structure and interactions within microbial food webs has led to efforts to describe them

\footnotetext{
- M. marina is also described in Larsen \& Patterson (1990), and as both manuscripts are being submitted at the same time, some guidance on the nomenclatural authority is appropriate. We treat Larsen \& Patterson (1990) as the authoritative nomenclatural publication and authorship is to be considered as dating from that work, even in the event of it being published after this communication
}

(Patterson \& Fenchel 1985, Fenchel \& Patterson 1986, 1988, Vørs 1988, Larsen \& Patterson 1990). Here we report on a protist, Massisteria marina ${ }^{*}$, that is specifically associated with planktonic and benthic detritus and appears to be widespread and common.

\section{MATERIALS AND METHODS}

Cultures were established by dilution series from water samples taken in the Limfjord (Denmark), and were maintained in $0.45 \mu \mathrm{m}$ filtered or artificial seawater with boiled wheat grain or added bacteria (Pseudomonas or Klebsiella aerogenes) at about $10^{\circ} \mathrm{C}$.

The same organism was isolated from profundal samples were taken using a multicorer (Barnett et al. 1984) during RRS 'Discovery' Cruise 168 in 1987 (Sample $11543,20^{\circ} 29.3^{\prime} \mathrm{N}, 18^{\circ} 27.6^{\prime} \mathrm{W}$, depth $1515 \mathrm{~m}$; and $20^{\circ} 28.9^{\prime} \mathrm{N}, 18^{\circ} 28.3^{\prime} \mathrm{W}$, depth $1590 \mathrm{~m}$ ). It was also found in 250 and $750 \mathrm{~m}$ samples from the water column taken during RRS 'Discovery' BOFS/JGOFS cruise (Station $11872,47^{\circ} \mathrm{N}, 20^{\circ} \mathrm{W}, 7$ July 1989). Protistan populations were monitored by light-microscopy of living material in organically enriched mixed cultures at atmospheric pressure and $10^{\circ} \mathrm{C}$

The same species was observed in intertidal sediments from the Severn Estuary (England), Portaferry (N. Ireland), Laucala Bay (Fiji), Queensland (Australia), 
Panama, Rio de Janeiro (Brazil), and Hawaii (see Larsen \& Patterson 1990 for details)

Light microscopy was conducted as described by Patterson (1982). For electron microscopy, aggregates of detritus from cultures were fixed with $5 \%$ glutaraldehyde with or without $0.1 \%$ osmium tetroxide in $7 \%$ sucrose and $100 \mathrm{mM}$ phosphate buffer at $\mathrm{pH} 7.4$. Fixed material was washed in sucrose-buffer, embedded in $2 \%$ agar, dehydrated as small blocks and embedded in Araldite resin. Sections were stained with lead and uranyl.

\section{OBSERVATIONS}

\section{Light microscopy}

Trophic cells. The body of trophic cells measures 2.5 to $5 \mu \mathrm{m}$ (average ca $4 \mu \mathrm{m}$, one cell from the Severn Estuary measured $9 \mathrm{~km}$ ), is dorso-ventrally flattened, has an irregular profile, and has 2 short inactive flagella curved over the (dorsal) surface of the cell away from the substrate (Figs. 1 and 2). The flagella may be absent from some cells. The cell body gives rise to 2 to 10 thin parallel-sided pseudopodia that may extend in excess of 10 times (usually 4 to 5 times) the body diameter away from the cell and are in contact with the substrate. The pseudopodia often branch and may anastomose; they carry small granular bodies (Figs. 1 to 3). There is little cytoplasmic activity in the pseudopodia. There is usually 1 nucleus (occasionally 2) with a central nucleolus. About half the cells have a refractile granule less than $0.5 \mu \mathrm{m}$ in diameter near the flagella. The cells frequently occur in clusters (Figs. 1c and 3), and pseudopodia of adjacent cells sometimes join together (Fig. 3). Electron microscopy reveals that cells in clusters are often in cytoplasmic continuity. Massisteria marina cells normally feed on bacteria.

Transformation and motile cells. If microscopic preparations of heavily bacterized cultures are maintained under a cover slip for more than a few minutes, some cells transform into flagellates without arms (Figs. $1 \mathrm{~d}$ to $\mathrm{f}$, and 4 to 11 ). During transformation, the pseudopodia shorten, thicken and are resorbed (Figs. 7 to 11). The flagella lengthen somewhat and become active. The transformed flagellates are pliable but not metabolic (i.e. do not actively squirm), and measure up to $15 \mu \mathrm{m}$ in length. They are pear-shaped, often with the posterior part drawn out as a relatively stiff spike (Figs. 4 to 6). Sometimes 2 or more flagellates attach to each other (Fig. 1e, f), as if all cells in a cluster transform simultaneously. No feeding by flagellates was observed

The flagella of transformed cells insert subapically, and their beating often deforms the cell. The proximal half of the posterior flagellum is usually thicker than the distal half (Fig. 4). The nucleus is located in the broadest part of the flagellate, and a refractile granule is frequently seen adjacent to the flagella. Flagellates may swim actively, or may glide with the posterior flagellum trailing against the substrate. No cysts with walls were observed.

\section{Electron microscopy}

Most cells have 2 flagella (Fig. 12) that normally lie parallel to the cell surface (Fig. 14). Cells of some populations had a thin layer of surrounding mucus (Fig. 19) and in these, as in some other cells, flagella were reduced in length or absent.

The flagellar axoneme has a conventional $9+2$ structure (Fig. 15), there being no accessory structures such as paraxial rod or flagellar hairs or scales. The transitional plate is slightly raised at its centre, and the central pair of microtubules end slightly above it at a disc-shaped or lens-shaped axosome (Figs. 14 and 23). The kinetosomes of the flagella are inclined at an acute angle to each other and end near the nucleus (Fig. 12) The inner ends of the kinetosomes are surrounded by a thin layer of amorphous electron-dense material (Figs. 12,14 and 23). The kinetosomes give rise to a small and variable number of microtubules which pass inwards (Fig. 12) and/or up towards the cell surface (Figs, 16 and 17 ).

The pseudopodia are thin extensions from the cell and are supported by one or several microtubules (Figs. 18 and 23). More substantial pseudopodia are used to engulf food particles (Fig. 19). Small extrusomes occur on the pseudopodia or under the membrane over the cell body. They have a concentric substructure (Fig. 20), the apex of the core is often expanded as a cap (Fig. 21). Coated vesicles are also formed at the surface of the cell (Fig. 22).

There is a single dictyosome in trophic cells. It is located adjacent to the nucleus alongside one of the kinetosomes (Fig, 24). It receives vesicles from the surface of the nucleus (Fig. 25). We believe that this is the refractile granule observed near the bases of the flagella - particularly in the motile cells.

The cell contains several mitochondria with tubular cristae (Fig. 28).

The nuclei have central nucleoli. The outer face of the nuclear envelope bears ribosomes (Fig. 28). Adjacent to the nucleus is a homogeneous electron-dense paranuclear body (Figs, 28 and 29). It is bound by a single membrane that is not continuous with the nuclear envelope, and is often surrounded by a fold of rough endoplasmic reticulum (Fig. 29).

As a prelude to cell division, flagellar replication 
Fig. 1. Massisteria marine. (a) Typical solitary cell with radiating branching pseudopodia with granules and 2 flagella curled inactively on the dorsal (away from substrate) side of the cell. (b) Cell with only 2 pseudopodia. (c) Typical arrangement of cells in a cluster as observed compressed upon a microscope slide. (d) Three individual motile cells. (e, f) Fused motile cells. Scale bar $=5 \mu \mathrm{m}$

precedes mitosis. During mitosis the nucleus develops large polar fenestrae through which spindle microtubules extend to make contact with the chromosomes (Figs. 26 and 27).

\section{DISCUSSION}

Having been isolated from littoral, oceanic and profundal waters, from tropical and temperate regions, from the Pacific and Atlantic, and from the northern and southern hemisphere (Larsen \& Patterson 1990), Massisteria marina clearly is geographically widespread. The ease and frequency with which it is found indicates that it is abundant.

The organism was invariably associated with detritus - whether in the water column or in sediments. As carbon flux through detritus makes a significant contribution to the total flux in the water column (Goldman 1984, Biddanda 1988, Biddanda \& Pomeroy 1988), organisms affecting the rate of remineralization are of considerable interest. One route of remineralization is via bacterial degradation. Protozoan predation on bacteria can accelerate this process (Fenchel \& Harrison 1976). Hence the diversity of bacterivorous flagellates is of relevance to the pathways of remineralization.

Marine bacterivorous flagellates are often thought of as motile organisms which feed on suspended bacteria. Massisteria marina challenges this concept as it is not normally motile and does not filter bacteria from the water column. Yet, this species is common and clearly must have available to it resources that are as wide-

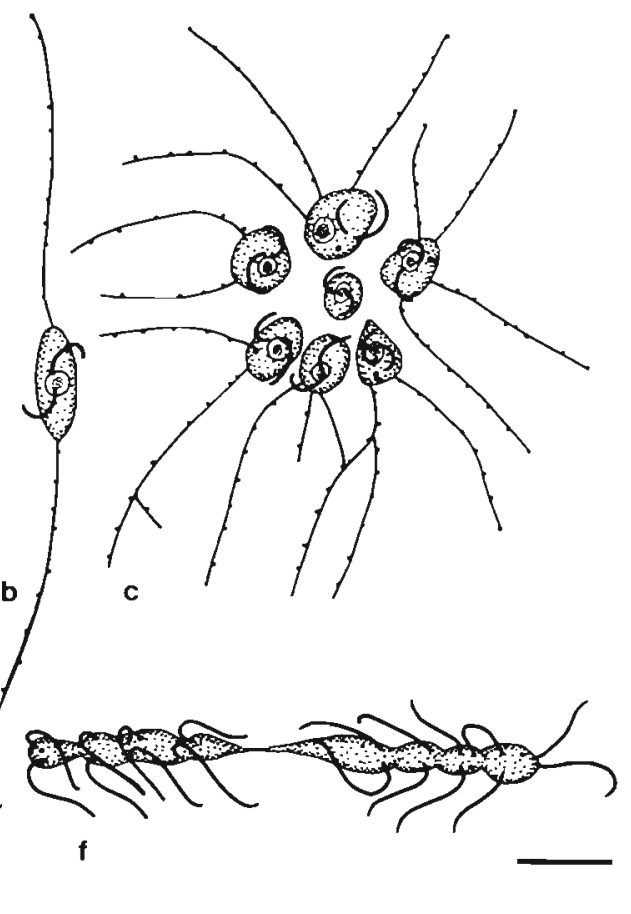

spread as bacteria in suspension. Its biology suggests that it occupies a predictable niche.

Bacterivorous flagellates associated with detritus appear to be adapted to feeding in one of 4 ways. Firstly, some species consume bacteria by ingesting larger masses of detritus. Such flagellates have yet to be reported from oceanic detritus but they are well represented in intertidal benthic ecosystems - mostly by phagotrophic euglenids (Patterson et al. 1989). Secondly, most species described to date from oceanic detritus remove bacteria from the surrounding water usually by filter-feeding; the group includes Percolomonas, collar flagellates, and actinomonad, chrysophytes, bicosoecids, and related stramenopiles (Caron et al. 1982, Fenchel 1982, 1986a, Fenchel \& Patterson 1986, 1988, Patterson 1989a). For most of these flagellates, the association with the detritus is transient and they may detach to swim away from the aggregates. Bacteria attached to the detritus are not accessible by filter-feeding (Fenchel 1986b) and are targets for the remaining 2 groups. The third type of flagellate includes the raptorial feeders (or 'nibblers') which consume individual bacteria associated with the accessible surfaces of detritus (Fenchel 1982, 1986a, 1987, Caron 1987, Mitchell et al. 1988, Patterson et al. 1989). So far there have been no descriptions of flagellates specifically adapted to the fourth way - feeding on bacteria within the detritus. This is the role we assign to Massisteria marina. The radiating pseudopodia armed with extrusomes will maximise chance contact with bacteria allowing us to view $M$. marina principally as a diffusion feeder (Fenchel 1987). 


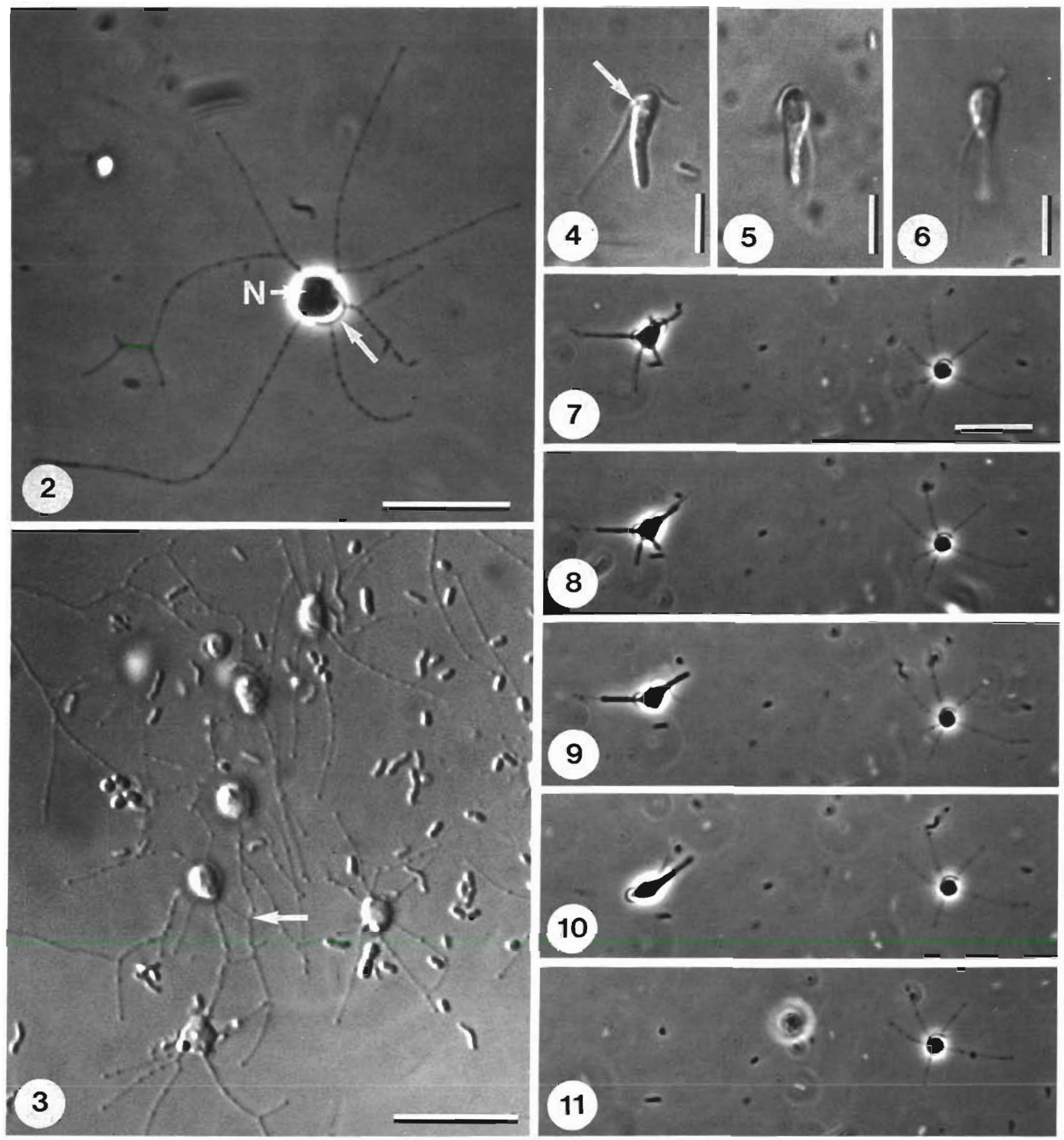

Figs. 2 to 11 Massisteria marina. Light micrographs of living cells. Fig. 2. Single trophic cell; arrow indicates flagellum; $\mathrm{N}=$ nucleus. Scale bar $=10 \mu \mathrm{m}$. Fig. 3. A cluster of cells; arrow indicates fusion of pseudopodia arising from different cell bodies. Scale bar $=10 \mu \mathrm{m}$. Figs. 4 to 6 . Motile cells; arrow in Fig. 4 indicates refractile body. Scale bars $=5 \mu \mathrm{m}$. Figs. 7 to 11. Transformation of cell with shortening and thickening of arms (Figs. 7 to 9) until a cell without arms is formed (Fig. 10) which then swims away (Fig

11). Scale bar $=10 \mu \mathrm{m}$

Aggregates of detritus are geographically patchy resources of carbon. They are also short-lived as the carbon can be burnt-off by microbial activity or aggregates may disintegrate. They may also become unsuitable habitats as the detritus settles into waters with differing physico-chemical characteristics. This resource exists as an archipelago of habitable islands isolated from each other in space and time. In order to successfully exploit these resources, populations will require survival strategies that will allow them to suc- 


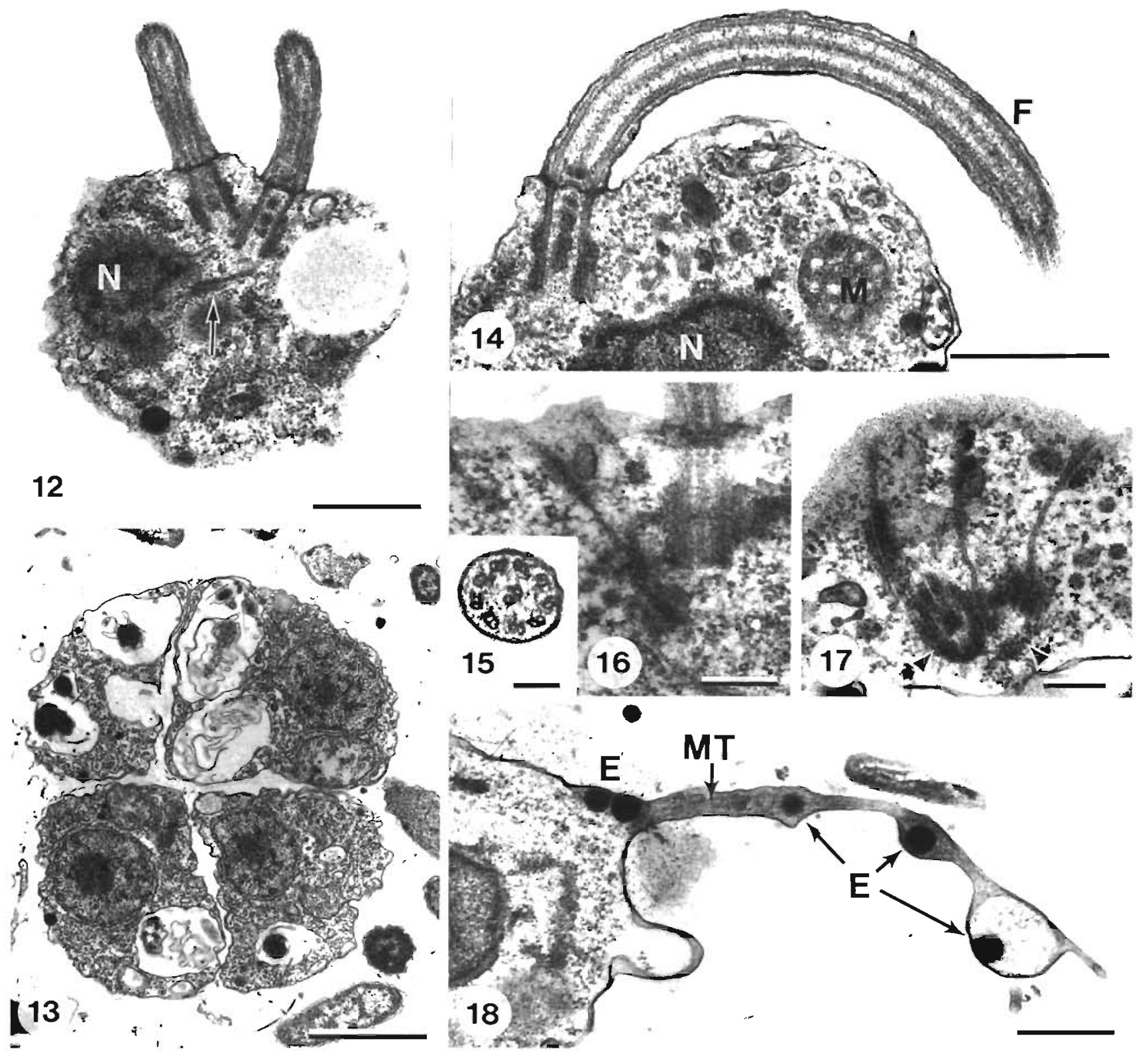

Figs. 12 to 18. Massisteria marina. Transmission electron micrographs of sectioned material. Fig. 12. Vertical section through the centre of the cell and including the 2 flagella. There is a short root (arrow) directed from the base of the flagella to the nucleus (N). Scale bar $=0.5 \mu \mathrm{m}$. Fig. 13. Cluster of 4 cells. Scale bar $=1.0 \mu \mathrm{m}$. Fig. 14. Longitudinal section through $1 \mathrm{flagellum}(\mathrm{F})$, showing axosome and transitional plate with raised centre. $\mathrm{M}$ : mitochondrion. Scale bar $=0.5 \mu \mathrm{m}$. Fig. 15. A cross section of an axoneme. Scale bar $=0.1 \mu \mathrm{m}$. Fig. 16. Longitudinal section through a kinetosome, showing 2 associated microtubules extending to the surface of the cell. Scale bar $=0.2 \mu \mathrm{m}$. Fig. 17. Transverse section through 2 kinetosomes showing 3 associated microtubules extending under the plasma membrane. Scale bar $=0.2 \mu \mathrm{m}$. Fig. 18. Longitudinal section through part of a pseudopodium, with microtubules (MT) and extrusomes (E), the two on the right are not in the resting state. Scale bar $=0.5 \mu \mathrm{m}$

cessfully move from one island to another. Many freeliving and parasitic protozoa face similar problems (Fenchel 1987). The principle option used by oceanic bacterivorous flagellates is dispersibility - the tendency to detach from detritus and to swim. This favours invasion of another island (Goldman 1984, Biddanda \& Pomeroy 1988). This phenomenon is not remarkable if we only consider the 'classical' (i.e. filter-feeding) he- terotrophic flagellates because there is little difference between organisms using flagella to propel fluid relative to their bodies (feeding) and those using flagella to propel their bodies relative to fluid (dispersal). The phenomenon of adaptive dispersibility does become evident when we include organisms such as Massisteria marina or if comparisons are made between organisms from oceanic and benthic ecosystems. In 

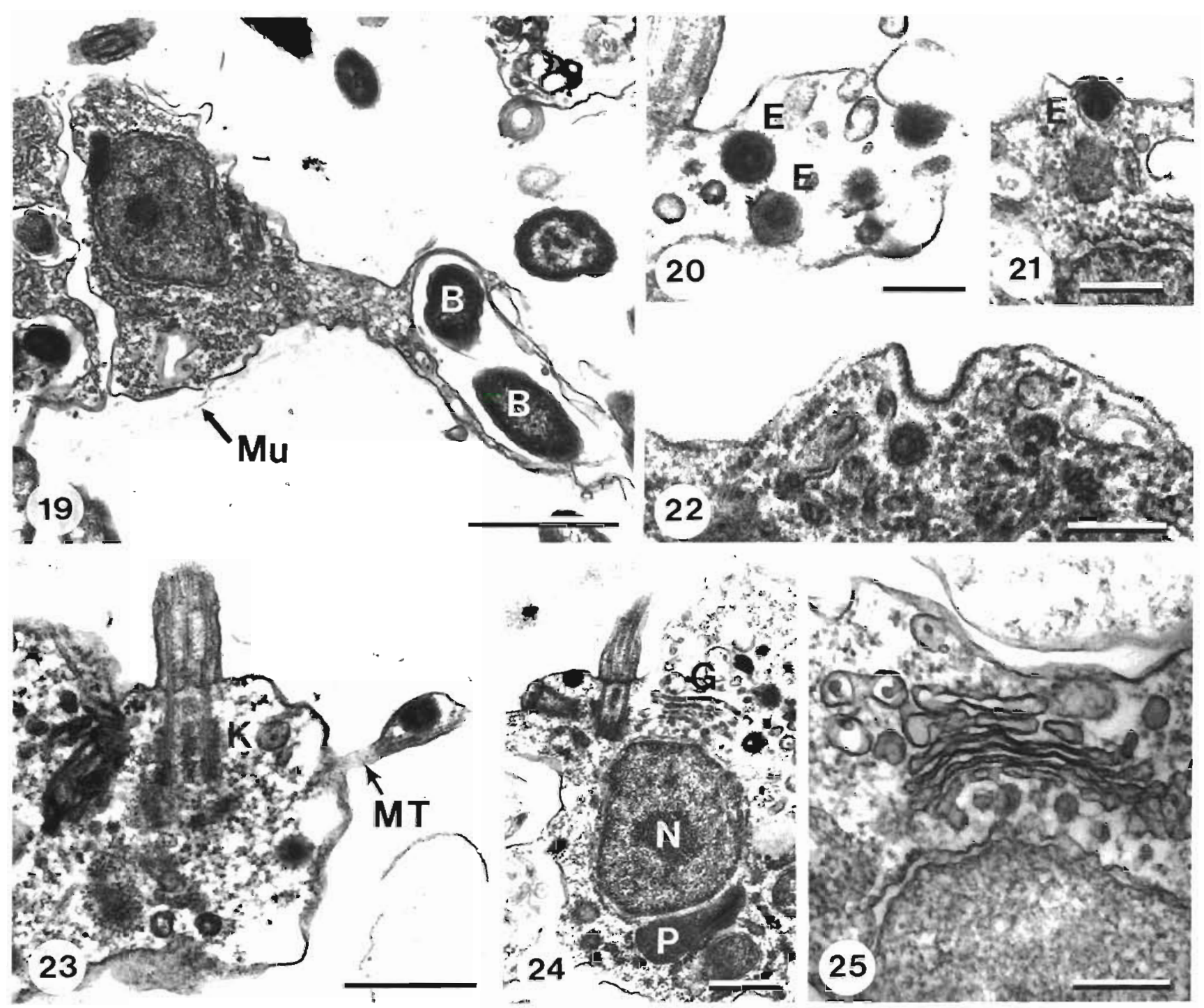

Figs. 19 to 25. Massisteria marina. Transmission electron micrographs of sectioned material. Fig. 19. Feeding cell taking in bacteria $(B)$ by pseudopodial engulfment. Mu: mucus. Scale bar $=1.0 \mu \mathrm{m}$. Fig. 20. Extrusomes (E) in cross section, showing concentric substructure. Scale bar $=0.2 \mu \mathrm{m}$. Fig. 21. Longitudinal section through extrusome (E), showing columnar capped appearance. Scale bar $=0.2 \mu \mathrm{m}$. Fig. 22. Coated vesicle forming at the surface of the cell. Scale bar $=0.2 \mu \mathrm{m}$. Fig. 23 . Longituctinal section through a kinetosome $(K)$, revealing dense material aggregated within and around the outer margins of the basal part of the organelle. Grazing section through pseudopodium shows microtubules (MT). Scale bar $=0.5 \mu \mathrm{m}$. Fig. 24 . Section through the centre of a cell showing the dictyosome (G) near the flagellar base and against the surface of the nucleus. Paranuclear body (P) is located away from this region of the nucleus $(N)$. Scale bar $=0.5 \mu \mathrm{m}$. Fig. 25. Dictyosome apparently receiving vesicles from the surface of the nucleus. Scale bar $=02 \mu \mathrm{m}$

benthic ecosystems the phenomenon of dispersibility is not as widespread (Patterson et al. 1989), and indeed those organisms lacking this capacity (e.g. phagotrophic euglenids, Protaspis, Metromonas) have failed to exploit sedimenting aggregates of detritus.

The stimulus for transformation and dispersal by Massisteria marina appears to be inappropriate physico-chemical conditions because, when transformation occurs, other flagellate species in the samples often show signs of physiological distress associated with overheating or hypoxia (loss of shape and activity).
The phylogenetic relationships of this taxon are not discussed in the original description (Larsen \& Patterson 1990). The star-shaped body form is adopted by a wide variety of taxa such as Gymnophrys (Cienkowski 1876), Cercobodo (Skuja 1948), Pseudospora and Protomonas (Doflein \& Reichenow 1928), Actinomonas vernalis' (Stokes 1885, 1888), Rhizochromulina and Rhizochrysis (Pascher 1917), a variety of cristidiscoid amoebae (Frenzel 1897, Patterson 1983, 1984), as well as many radiolaria, heliozoa and granuloreticulose amoebae. This body form is highly adaptive and is not 

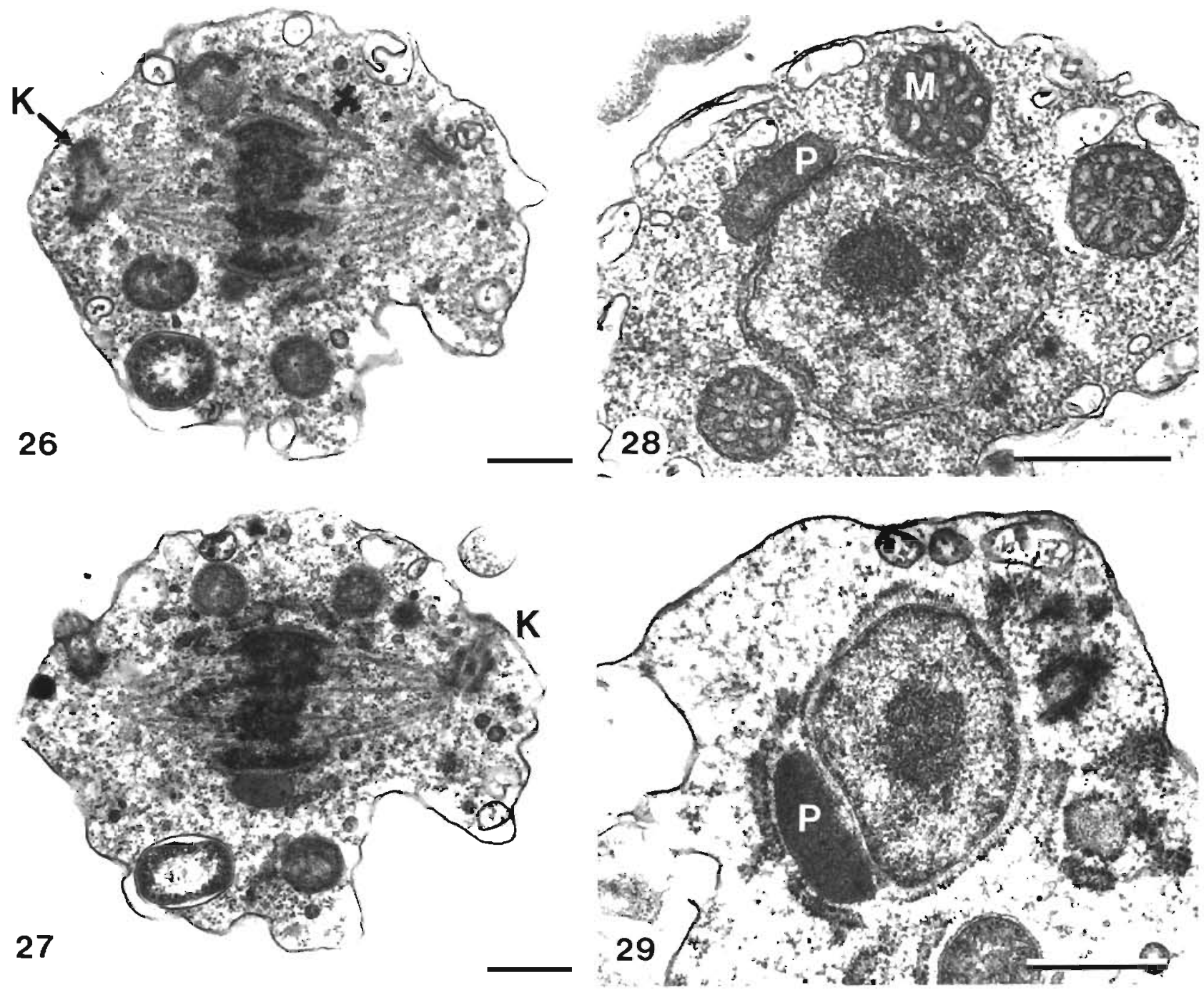

Figs. 26 to 29. Massisteria marina. Transmission electron micrographs of sectioned material. Figs. 26, 27. Sections from a series through dividing nucleus at metaphase, showing spindle microtubules nucleating on kinetosomes (K) at opposite poles of the cell, and the nuclear envelope with large breaks near the poles. Figs. 28, 29. Typical interphase nucleus with paranuclear body (P); in

Fig. 28 the body is enclosed within a fold of endoplasmic reticulum. M: mitochondrion. All scale bars $=0.5 \mu \mathrm{m}$

indicative of specific relationships. The greatest light microscopical similarity is with Microcometes (Valkanov 1931) and Gymnophrys (Cienkowski 1876, Penard 1902) because members of all 3 genera are small amoeboid organisms having pseudopodia which support small extrusomes.

Electron microscopical studies provide protist taxa with ultrastructural identities (Patterson \& Brugerolle 1988) which have proven useful in clarifying relationships (Patterson 1989a, b). Of the 2 taxa which most closely resemble Massisteria from a light-microscopical perspective, Microcometes has not been studied ultrastructurally. Gymnophrys, though thought of as an amoeboid organism, has kinetosomes with or without short flagella and has small concentric extrusomes (Patterson unpubl.). Gymnophrys differs from Massisteria because (1) it does not have a paranuclear body; (2) it has flat mitochondrial cristae; (3) it has large numbers of cytoplasmic microtubules; (4) the pseudopodia are invariably supported by microtubules; and (5) it has 2 plates forming the transitional zone of the flagella. The ultrastructural identities are sufficiently different to argue against a close relationship between Massisteria and Gymnophrys.

Massisteria does share with the flagellates Bodomorpha and Cercobodo the feature of a homogeneous paranuclear body. The type species of Bodomorpha was originally described as Pseudobodo minima (Hollande 1942), with a novel generic name being created later (Hollande 1952) for nomenclatural reasons. Bodomorpha reniformis was added by Zhukov (see Mylnikov 1984). Bodomorpha has a parabasal cor- 
puscle (Hollande 1942, Zhukov 1971) comprised of dictyosomal material (Zhukov 1971). We believe that this feature occurs in Massisteria as the refractile granules. Bodomorpha has concentric extrusomes and tubular mitochondrial cristae, but differs from Massisteria in having cross-striated rootlets associated with the basal body and (probably) a well developed cartwheel structure at the base of the kinetosome (Mylnikov 1984). The 2 accounts (Mignot \& Brugerolle 1975, Mylnikov 1986) of Cercomonas ultrastructure suggest similar features in that genus, although the accounts differ with respect to extrusomes. Some species of Cercomonas may produce radiating arms (Skuja 1948).

Principally on the evidence of the paranuclear body, we suggest that the genera Cercomonas, Bodomorpha, and Massisteria are closely related. This case is tenuous and, until the argument can be strengthened with more information, we feel that it would be inappropriate to proffer a new taxon to house these genera.

Acknowledgements. We thank K. Williams for his able technical assistance. D. J. P. acknowledges financial support of the Royal Society of London (light microscope), and of the Natural Environment Research Council (BOFS special topic). BOFS publication no. 3 .

\section{LITERATURE CITED}

Azam, F., Fenchel, T., Field, J. G., Gray, J. S., Meyer-Reil, L.A., Thingstad. F. (1983). The ecological role of water column microbes in the sea. Mar. Ecol. Prog. Ser 10: 257-263

Bak, R. P. M., Nieuwland, G. (1989). Seasonal fluctuations in benthic protozoan populations at different depths in marine sediments. Neth. J. Sea Res. 24: 37-44.

Barnett, P. R. O., Watson, J., Connelly, D. (1984). A multiple corer for taking virtually undisturbed samples from shelf, bathyal and abyssal sediments. Oceanologica Acta 7: 399-408

Biddanda, B. A. (1988). Microbial aggregation of phytoplankton-derived detritus in sea water. II. Microbial metabolism. Mar. Ecol. Prog. Ser 42: 89-95

Biddanda, B. A., Pomeroy, L. A. (1988). Microbial aggregation of phytoplankton-derived detritus in sea water. I. Microbial succession. Mar Ecol. Prog. Ser. 42: 79-88

Caron, D. A. (1987). Grazing of attached bacteria by heterotrophic microflagellates. Microb. Ecol. 13: 203-218

Caron, D. A., Davis, P. G., Madin, L. P., Sieburth, J. McN. (1982). Heterotrophic bacteria and bacterivorous protozoa in oceanic macroaggregates. Science 218: 795-796

Cienkowski, L. (1876). Ueber einige Rhizopoden und verwandte Organismen. Arch. Mikr. Anat. $12 \cdot 15-50$

Davoll, P. J., Silver, M. W. (1986). Marine snow aggregates: life history sequence and microbial community of abandoned larvacean houses from Monterey Bay, Califomia. Mar Ecol. Prog. Ser. 33: 111-120

Doflein, F., Reichenow, E. (1928). Lehrbuch der Protozoenkunde, 5th edn, II. Teil. Gustav Fischer, Jena, p. 439-862

Ducklow, H. W. (1983). Production and fate of bacteria in the oceans. Bioscience 33: 494-501

Fenchel, T (1982). Ecology of heterotrophic microflagellates. IV. Quantitative occurrence and importance as consumers of bacteria. Mar. Ecol. Prog. Ser. 9: 35-42
Fenchel, T (1986a). The ecology of heterotrophic flagellates. Adv. Microb. Ecol. 9: 57-97

Fenchel, $T$ (1986b). Protozoan filter feeding. Progr. Protistol. 1. $65-113$

Fenchel, T (1987). Ecology of Protozoa. Science Tech. Publishers; Madison, Wisconsin and Springer-Verlag, Berlin

Fenchel. T., Harrison, P. (1976). The significance of bacterial grazing and mineral cycling for the decomposition of particulate detritus. In: Anderson J. M. (ed.) The role of terrestrial and aquatic organisms in decomposition processes. Blackwells Scientific Publishers, Oxford, 285-299

Fenchel, T., Patterson. D. J. (1986). Percolomonas cosmopolitus (Ruinen) $\mathrm{n}$. gen., a new type of filter feeding flagellate from marine plankton. J. mar. Biol. Ass. U.K. 66: 4565-484

Fenchel, T., Patterson, D. J. (1988). Cafeteria roenbergensis nov. gen, nov. sp., a heterotrophic microflagellate from marine plankton. Mar. Microb. Food Webs 3: 9-19

Frenzel, J. (1897). Untersuchungen über die microskopische Fauna Argentieniens. Erster Teil: Die Protozoen. I. und II. Abteilung: Die Rhizopoden und Helioamoeben. Biblthca Zool. 12: 1-166

Goldman, J. C. (1984). Conceptual role for microaggregates in pelagic waters. Bull. mar. Sci. 35: 462-476

Hollande, A. (1942). Étude cytologique et biologique de quelques flagellés libres. Volvocales, Cryptomonadines, Eugléniens, Promastigines. Archs Zool. exp. gén 83: 1-268

Hollande, A. (1952). Classe des Bodonidés. In: Grassé, P. P. (ed.) Traité de Zoologie, Tome 1. Masson et Cie, Paris, p. 669-693

Karl, D. M., Knauer, G. A., Martin, J. H. (1988). Downward flux of particulate organic matter in the ocean: a particle decomposition paradox. Nature, Lond. 332: 438-441

Larsen, J., Patterson, D. J. (1990). Some flagellates (Protista) from tropical marine sediments. J. nat. Hist. (in press)

Mignot, J. P., Brugerolle, G. (1975). Etude ultrastructurale de Cercomonas Dujardin (= Cercobodo Krassilstchick), protiste flagellé. Protistologica 11. 547-554

Mitchell, G. C., Baker, J. H., Sleigh, M. A. (1988). Feeding of a freshwater flagellate, Bodo saltans, on diverse bacteria. J. Protozool. 35: 219-222

Mylnikov, A. P. (1984). Characteristic features of the fine structure of Bodomorpha reniformis Zhukov (Zoomastigophorea). Tsitologiya 26: 1308-1310

Mylnikov, A. P. (1986). Characteristic features of the ultrastructure of Cercomomas varians Skuja. Tsitologiya 28 : $414-417$

Pascher, A. (1917). Flagellaten und Rhizopoden in ihren gegenseitigen Beziehungen. Arch. Protistenk. 38: 1-79

Patterson, D. J. (1982). Photomicrography using a dedicated electronic flash. Microscopy $34: 437-442$

Patterson, D. J. (1983). On the organization of the naked filose amoeba, Nuclearia moebiusi Frenzel, 1897 (Sarcodina, Filosea) and its implications. J. Protozool. 30: 301-307

Patterson, D. J. (1984). The genus Nuclearia (Sarcodina, Filosea): Species composition and characteristics of the taxa. Arch. Protistenk. 128: 127-139

Patterson, D. J. (1989a). Stramenopiles: chromophytes from a protistan perspective. In: Green, J., Leadbeater, B. S. C., Diver, $W$ L. (eds.) Chromophyte algae: problems and perspectives. Clarendon Press, Oxford, p. 357-379

Patterson, D. J. (1989b). The evolution of Protozoa. Mem. Inst Oswaldo Cruz Rio de J. 83 (suppl. 1): 580-600

Patterson, D. J., Brugerolle, G. (1988). The ultrastructural identity of Stephanopogon apogon and the relatedness of this genus to other kinds of protists. Eur J. Protistol 23 279-290 
Patterson, D. J., Fenchel, T (1985). Insights into the evolution of heliozoa (Protozoa, Sarcodina) as provided by ultrastructural studies on a new species of flagellate from the genus Pteridomonas. Biol J. Linn. Soc. 34: 381-403

Patterson, D. J., Larsen, J., Corliss, J. O (1989). The ecology of heterotrophic flagellates and ciliates living in marine sediments. Progr Protistol. 3: 185-277

Penard, E. (1.902). Faune Rhizopodique du bassin du Léman. Kündig, Geneva. 1-714

Proctor, L. M., Fuhrman, J. A. (1990). Viral mortality of marine bacteria and cyanobacteria. Nature, Lond. 343: 60-62

Skuja, H. (1948). Taxonomie des Phytoplanktons einiger Seen in Uppland, Schweden. Symbol. bot. Upsal 9: 1-399

Stokes, A. C. (1885). Some new infusoria from American fresh waters. Ann. Mag. Nat. Hist. series 5 15: $437-449$

Stokes, A. C. (1888). A preliminary contribution toward a

This article was submitted to the editor history of the fresh-water infusoria of the United States Journal Trenton Natural History Society 1: 71-319

Valkanov, A. (1931). Beitrag zur Morphologie und Karyologie der Microcometes paludosa Cienk. Arch. Protistenk. 73: $367-370$

Vors, N. (1988). Discocelis saleuta gen. nov. et sp. nov. (Protista incertae sedis) - A new heterotrophic marine flagellate. Eur J. Protistol. 23: 297-308

Wiebe, W. J., Pomeroy, L. R. (1972). Microorganisms and their association with aggregates and detritus in the sea: a microscopic study. Memorie Ist. ital. Idrobiol. 29 (suppl.): $325-352$

Zhukov, B. F. (1971). (A key to the free-living flagellates of the suborder Bodonina Hollande]. Trudy Inst. Biol. vnutren. vod 21: $241-284$

Manuscript first received: July 17, 1989

Revised version accepted: January 17, 1990 